\title{
TEACHERS' BELIEFS ON TEACHER-STUDENTS INTERACTION IN YOUNG LEARNERS' ENGLISH CLASS
}

\author{
Maria Setyaningsih Nernere \\ Faculty of Business and Economics, Universitas Atma Jaya Yogyakarta, Yogyakarta, Indonesia \\ E-mail: maria_setyaningsih@staff.uajy.ac.id
}

APA Citation: Nernere, M. S. (2019). Teachers' beliefs on teacher-students interaction in young learners' English class. Indonesian EFL Journal, 5(2), 113-120. doi: 10.25134/ieflj.v5i2.1903.

\begin{abstract}
Researchers find that teacher plays dominant role in managing the teacher- students interaction, the important aspect affecting the language acquisition process in young learners' class. Hence, to make sure that the teacher-students interaction goes well for achieving the classroom goals, how the teacher manages the interaction should be investigated further. As beliefs can affect how people act, this research aims to investigate the teachers' belief on teacher-students interaction in young learners' English class. This is a qualitative research using direct observation in two English classes at two different Elementary schools and in-depth interview with two English teachers as the data collecting techniques. The data revealed that the teachers' beliefs affecting how the teacher-students interaction goes consist of beliefs about goals, process, and source of teacher- students interaction. Overall, the interactions were done to achieve two goals namely promoting language acquisition and controlling learning atmosphere. The source of interaction namely teacher talk was adjusted to young learners' characteristics to make the process of learning meaningful. This finding gives conceptual insight about how the system of teacher-students interaction in English learning process in Elementary schools works. Then, it may be beneficial for the teachers as a means supporting selfreflection, schools' evaluation and also for the educational practitioners who want to investigate the TSs interaction in more details.
\end{abstract}

Keywords: English class; teachers' beliefs; teacher-students interaction; young learners.

\section{INTRODUCTION}

The importance of classroom interaction for English learning has been acknowledged by English for young learners' practitioners. It motivates them to analyze the pattern, causal factors, effects, and other aspects of interaction by researching the interaction in different setting, subject learnt or age level of participants and using different research methodology. In Indonesia, many practitioners have concerned on researching young learners' classroom interaction. Many of them focused on analyzing the surface of interactions such Wibowo (2017) who described the pattern of classroom interaction and Ani (2017) who analyzed the type of classroom interaction.

From those researches, it was found that each pattern of classroom interaction namely teacher- students (TSs) interaction, teacherstudent (TS) interaction, and student-student (SS) interaction plays its own role for the success of English learning. Chowdhury and Rashid (2014) found that young learners are willing to engage in learning only if the teaching and learning process is meaningful to them. Here is the role of TSs interaction. How the interaction can accommodate meaningful learning is very important in young learners' language classroom. Young learners do not directly learn from textbooks but they practice and tend to learn indirectly through the interaction that they experience in classroom. Thus, interaction has role for effectual learning environments and in shaping of individual learners' development. Due to Hammond's model of language teaching, TSs interaction plays big role during the process of teaching learning before the students produce the text independently. Believing that TSs plays bigger role for the success of language production, Makasau (2015) went into details by researching the adjacency pairs occurring 
in the teacher-students interaction. Hoque (2016) also emphasized that TSs interaction has essential role for promoting success in EFL education pedagogy affects.

Acknowledging the importance of investigating TSs interaction for the learning success from the previous researches, it is needed to investigate further the reality of TSs interaction in English classroom in Indonesia. The existing investigations mainly focused on researching the surface of the TSs interaction. The fact is that TSs interaction in young learners class is dominantly managed and initiated by the teacher (Makasau, 2015). Teachers may have purpose in mind so that they lead the interaction, guide the process and evaluate the result.

In fact, what people believe affects what they do. It happens also in education in which what teachers believe was also applied in their teaching practices (Utami, 2016). It means that all decision that teachers have for TSs interaction is affected by their knowledge and belief. In classroom setting, belief affects the teachers' decision on holding the teaching and learning process as proven by Fajrinur (2018). Considering the important of belief, Puspitasari (2013) investigates the teachers' belief in English teaching in Elementary stage to find out how the teaching goes.

Considering the importance of TSs interaction for the success of learning and the dominant role of belief in influencing the teacher who dominantly takes part in the TSs interaction, this current research focuses on investigating the teachers' belief in TSs interaction. Many researchers have concerned on TSs interaction. They were Petek (2013) investigating the teachers' belief in classroom interaction and $\mathrm{Chu}$ (2014) discussing the belief of TSs interaction in kindergarten. Unfortunately, they have not investigated teachers' belief in TSs interaction in Elementary stage deeper. This is the gap that this research tries to concern on. The findings from the existing theories are used as the references for this research. Pattern and forms of interaction that the teacher believes to work in constructing meaning in the real English class are observed. The reasons behind having such interaction are also investigated further. Specifically, this research focuses on investigating the TSs interaction in young learners' classrooms in private schools. By researching the teachers' belief, the concept of TSs interaction in elementary schools can be illustrated especially related to the system of TSs interaction consisting of the goals, process, and its sources.

\section{METHOD}

Considering belief as a value, qualitative research methodology was chosen to be applied in this research. The data was collected by doing direct observation in four and five graders in two different SD Kanisius in Yogyakarta resulted into observation notes and having depth- interview to two teachers teaching those English classes recorded in interview transcript. The last interview was done to cross- check the result of data analysis. In this research, the process of analyzing data was adopted from Creswell (2014). It consists of collecting data, preparing data for analysis, reading through data, coding the data, and coding the text for themes and description to be used in the research report. Here is the example for template of the coding and theme.

\begin{tabular}{|c|c|c|c|c|c|}
\hline \multicolumn{2}{|c|}{ Num } & Subject & Script & Coding & \multirow{10}{*}{$\begin{array}{c}\text { initiatio } \\
n- \\
\text { process }\end{array}$} \\
\hline \multicolumn{5}{|c|}{$\begin{array}{l}11.55 \\
\text { The teacher came into the class and get } \\
\text { prepared. The teacher started the lesson } \\
\text { by greeting the students. The students } \\
\text { answered it using the pattern that they } \\
\text { have accustomed to. }\end{array}$} & \\
\hline 1 & $\mathrm{~T}$ & $\begin{array}{l}\text { Attenti } \\
\text { get set. }\end{array}$ & please, & giv inst & \\
\hline 2 & $\mathrm{Ss}$ & Get set & tand up). & & \\
\hline 3 & $\mathrm{~T}$ & $\begin{array}{l}\text { Good a } \\
\text { student }\end{array}$ & rnoon, & & \\
\hline 4 & Ss & $\begin{array}{l}\text { Good a } \\
\text { Ms Nar }\end{array}$ & rnoon, & & \\
\hline 5 & $\mathrm{~T}$ & $\begin{array}{l}\text { How is } \\
\text { with yo }\end{array}$ & erything & ask inf & \\
\hline 6 & Ss & $\begin{array}{l}\text { I am fir } \\
\text { you, an }\end{array}$ & $\begin{array}{l}\text { thank } \\
\text { you? }\end{array}$ & & \\
\hline 7 & $\mathrm{~T}$ & $\begin{array}{l}\text { I am fir } \\
\text { you. Si } \\
\text { please. }\end{array}$ & $\begin{array}{l}\text { too, thank } \\
\text { own, }\end{array}$ & $\begin{array}{l}\text { giv inf, } \\
\text { inst }\end{array}$ & \\
\hline 8 & Ss & Thank & & & \\
\hline
\end{tabular}




\section{RESULTS AND DISCUSSION}

After analyzing the data, it is found that teachers consider their beliefs on the goals, the process, and the sources of TSs Interaction while managing the TSs interaction. Here are the details.

\section{Goals of TSs interaction}

TSs interaction existed when the teacher and his/ her students exchanged their ideas. Based on the observation, the interaction was dominantly initiated by the teachers. As teachers, they might have goals in mind when they acted in classroom, including managing the TSs interaction with their students. Based on the data gathered, it is analyzed that the teachers believe that TSs interaction is aimed for promoting English language acquisition and increasing positive attitude toward learning.

\section{Promoting English language acquisition and learning}

Based on the observation, the teachers promote English as a language used to interact with their students. By exposing English to the students, the teachers expect that the students will acquire it. It is more preferable to be called as acquisition process than learning process since it happens through 'subconscious process' (Krashen, 1982 in Castello, 2015) during the interaction. On the other words, teachers do not merely see English as a means of communication but they also consider it as an input for language acquisition.

Having the same belief about English as input, Hoque (2016) states that through interaction with the teachers, the students can increase their language store. As a result, they can improve their language proficiency as the implicit knowledge. It is in line with input hypothesis proposed by Krashen (1985, 1994 in Castello, 2015) in which through understanding input that contains structures a little bit beyond the students' current level of competence, students may progress in acquisition. By acquiring language, the students can develop their speaking skill. Later on, it is expected that they are able to communicate easily in the future.
p-ISSN 2252-7427, e-ISSN 2541-3635

https://journal.uniku.ac.id/index.php/IEFLJ/index

Besides promoting English acquisition through exposing input, in TSs interaction, the teachers also promote acquisition through giving chance to the students for producing output. Producing output can be in the form of responding their teacher or initiating their ideas. The teachers consider that by producing output, the students may construct their understanding about the language. Found on the observation, the students were guided to process what they know and create it to be a new one. They created an interaction and produce language. The teachers have role in this interaction to assist the students' production. Mayer (2002) in Pianta, Hamre and Allen (2012) supports it by stating that this kind of process facilitates the ability to access and apply the language acquired which is needed in learning. If the students construct the language by themselves, the students will learn the language better. Based on the data, the teachers believe that students who participate on the interaction will understand and learn better than those who do not participate. This is why they often encourage the students to participate actively on the interaction. Making mistakes during the production is acceptable. Consequently, the teachers may give corrective feedback as the follow up.

\section{Increasing students' positive attitude toward learning}

Besides aiming to develop students' cognition through English language acquisition, TSs interaction is also aimed to increase the students' positive attitude toward learning. Attitude in this research refers to the students' engagement and students' motivation. First, in TSs interaction, teachers may manage their students' behavior verbally. It can be done by giving instructions to the students, reminding them about time allocation, and giving verbal warning to the misbehaved students. Those actions are aimed to keep the students engaged on the learning. Pianta, Hamre and Allen (2012) also agree on the benefit of TSs interaction for the behavior management. They state that TSs interaction "promote positive behavior and prevent or 
terminate misbehavior in the classroom (p.374)". If the behavior management is successfully done in class, the teacher may achieve an efficient learning since the students may understand at once. The teachers consider that their students are having short span of attention. It has been young learners' characteristic that is confirmed by Pinter (2011). Therefore, teachers often give verbal "reminder" to make the students aware and engaged in learning.

Second, the teachers may also increase students' attitude by communicating ideas e.g. sharing opinion and feeling in TSs interaction. They also spend time for talking about any ideas related to the students. One of the examples is when the teacher communicates with the students about the consequence of being noisy in class. They share and tolerate each other. Pinter (2011) states that negotiating class rules can bring students and the teacher closer together and also build warm and friendly relationship. Consequently, they may build a positive learning atmosphere.

Through sharing ideas, the teachers may know their students' condition. Once the teachers notice that the students are feeling demotivated, they will motivate their teachers verbally. In TSs interaction, the teachers also boost the students' confidence verbally to participate actively during the interaction. Nugent (2009) has also found that TSs interaction have role in influencing the students' motivation.

Consequently, the students will feel that the teachers care to them. Puspitasari (2013) states that this kind of affective supports may be beneficial for decreasing the students' language ego that can create a sense of fragility, defensiveness, and a rising of inhibitions. By creating supporting atmosphere, the students may feel comfortable in learning. Then, the students will be active and more engaged in learning English without worrying things e.g worry of being blamed if they make mistakes. This is why teachers do not only focus on learning for the whole session. As a result, there is a good communication resulting in positive relationship between the teachers and the students. Then, the students may have positive attitude toward learning. Zhu (2013) confirms this belief by stating that in the learning environment, teacher-students interaction plays a major role both in influencing the cognitive and affective development of students.

Third, the teachers may increase the students' attitude toward learning through creating supportive learning atmosphere. If the focus of the learning is only about discussing the materials, the students may feel bored. This is why in TSs interaction, the teachers sometimes make jokes to build fun atmosphere. Besides, sometimes the teacher uses Javanese language during the interaction to break the ice. Using Javanese language in English classroom is considered as funny thing by the students. Puspitasari (2013) states that if the students are happy, they will enjoy and benefit from their language learning.

\section{Process of TSs interaction}

In fact, interaction and acquisition do not happen simultaneously. Acquisition only happens if the input in TSs interaction is comprehensible. It is in line with comprehensible input proposed by Krashen (1985) in Ellis (2008). If the students do not understand the ideas, there is no language acquisition. This is why the teachers often asked the students' understanding in Indonesian language to make sure that they have understood.

Based on the data, there are many ways to make input comprehensible. First, the teachers interact using simple English. The teachers realized that they are talking to Elementary students who consider English as foreign language. Thus, the level of complexity should be adjusted to the students' proficiency.

Second, the teachers interact by using language that the students are familiar with. This is why the teachers only use English for classroom language instruction and any usual expressions. According to Nation (2007), to be learnt, an input should be the one that the 
students are familiar with. Only small numbers of unknown words are allowed. In fact, exposing simple language does not guarantee that the students will understand. Sometimes, there are some students who misunderstand or even do not understand although the teachers have made their explanation simple.

Third, the teachers use clues to help the students in comprehending the unfamiliar input. It aims to avoid the students' misunderstanding. Besides, it may make the language more understandable so the students can catch the meaning easily. Due to the input hypothesis proposed by Krashen (1985) in Ellis (2008), to come up in comprehension, the teachers should combine the simplifying input with the help of contextual and extra linguistic clues. Nation (2007) also supports on the use of clues in TSs interaction by stating that the learners can gain some knowledge of the unknown language items through contextual clues like reality, pictures, or situation and background knowledge.

Fourth, the teachers interact using English as a routine such as for greeting, closing, and other usual activity. It aims to make the students are accustomed to the language exposed to them. This strategy is in line with the time-on-task principle. This principle shows that the higher the frequency for doing something, the better the students are likely be at doing it (Nation, 2007). Thus, it is reasonable that the interaction done in a usual activity goes smoothly. If the language is exposed to the students for many times, the process for gaining it is easier. This is what Hatch and Gough (1976) in Ellis (2008) call with frequency hypothesis.

Realizing the importance of gaining input in TSs interaction, the teachers always demand their students to involve in. The teachers consider that learning happens only if the students involve in the interaction. Thus, on the beginning of the interaction, teachers often demand the students verbally to pay attention and participate on the interaction. In fact, Makasau (2015) also finds 'asking attention' as one of typical adjacency pairs found in TSs interaction. By paying attention on the talk, the students may be aware of the function, how it was pronounced and how to respond it. It is in line with noticing hypothesis proposed by Schmidt (2001) in Ellis (2008) who emphasizes the importance of noticing input and noticing the gaps as essential processes in L2 acquisition. He states that learners only learn what they consciously attend to in the input. Pinter (2011) also supports the importance of participating on the interaction since she considers that the students may get English exposure. As a result, the students may have the opportunity to acquire the language exposed to them.

Once they do not pay attention, they will not get the idea about what is being learnt. On the other hand, if they notice, they will learn. This is why teachers do some effort to get their students' attention, e.g. calling names and writing the important talk on the whiteboard. They realize that their students belong to young learners who have short span of attention as what Pinter (2011) confirms. In fact, there is no guarantee that the students who involve in the interaction will exactly acquire the language exposed to them. According to the teachers, the students who successfully acquire the language are those who can describe it in their first language (Indonesian language). As they respond on the interaction, it shows that they understand. The opportunity for learning will be bigger. During the observation, the teachers did not force the students to respond in English. The important point is that the students understand. As the follow- up, they will teach their students how to respond in English.

What is true is that students' responses in TSs interaction are useful for the teachers. The responses can be right or wrong. Both of them give valuable information. By acknowledging this error, the teachers can notice who have acquired and who have not and how far they have acquired the input. Later on, they can give follow- up. If the students do mistakes, the teacher can give corrective feedback. 
At other time, learners' correct responses can be used as input for other students. Since it happens during TSs interaction, other students can notice. Consequently, everybody has the same chance to acquire the language. However, the teachers realized that not all students could notice and participate actively during the whole TSs interaction. They considered about students who were difficult to focus.

As what has been discussed above, the focus of TSs interaction is not merely on learning content but also providing the learning atmosphere. Since it is a young learners' classroom, students' affective development is really concerned. If the students are demotivated, there will not be an acquisition. This is why teachers are aware of the students' motivation level. Thus, Javanese is preferred.

\section{Sources of interaction \\ Teacher talk}

Based on the results, teacher talk dominates the TSs interaction. According to Kumpulainen and Wray (2002), the role of the teacher was more salient and explicit in the whole class period. They may have their own purposes when delivering a talk to the students. As a result, it makes them play different roles in TSs interaction during the learning in the classroom. Besides affected by the goals, teacher talk exposed to the students is also affected by the students' proficiency. According to Chu (2014), the students' proficiency affects teacher in deciding which role that they play in the TSs interaction. Based on the observation, the teachers position themselves into three roles. First, the teachers position themselves as a controller.

They give direction to the students and manage them to follow the instruction as what they expect. They decide what the students should do and discuss. They evaluate the students' response to be as same as what they expect. On the other words, they control everything to get the expected results. It is the same as what Pujiastuti (2013) describes about the controller in classroom who is mainly giving direction, lecturing and asking question by which she led the flow of interaction. They may think that young learners need guidance during the learning. If there is no controller during the learning, the goal of learning cannot be achieved.

Second, the teachers also position themselves as manager. They guide the students to the goals by informing the goals on the early meeting and give freedom to the students in responding but keep monitoring by giving follow- up during the ongoing process if needed to keep the right track. Here is the explanation for IRF pattern found during the observation. They also keep motivating the students' performance by appreciating students talk, accepting student's feelings, praising the student's performance, and using student's ideas. Third, instead of playing role as resource, the teachers consider themselves as facilitator. They think that the students may have the ideas already. Thus, they only need to facilitate the learning and guide the students to find what should be learnt.

Besides considering different roles in TSs interaction, teacher also consider about the language used there. Based on the findings, the distribution of the use of Bahasa Indonesia, English, and Javanese language during the TSs interaction is $70 \%: 25 \%: 5 \%$. The teachers agree that the preference of language depends on the students' proficiency, students' motivation, and the purpose of talk. Pinter (2011) also supports it by stating that teachers vary widely in how much English they use in their classroom. It may depend on how comfortable they feel using English, the level of their pupils' language or the purpose of the talk. Consequently, the teacher should be sensitive about their students' proficiency. English is aimed for acquisition process in which the language should be comprehensible. While Bahasa Indonesia is aimed for helping the students understand the unfamiliar ideas. At the same time, Javanese language is also used for creating more relaxed atmosphere. 


\section{Student talk}

Though the teachers dominate the talk, it does not mean that the students are passive. In fact, the teacher talk may either boost the students' responses or motivate the students to initiate the interaction. It happens because the students are type of young learners who are keen to talk (Pinter, 2011), especially if they are interested to the topic. They will ask questions until they get clear understanding. Besides, they can be motivated to learn so that they can perform better. They might give statement or raise further question. Based on the observation, once the students knew the answer, they would respond to the teachers' questions. Moreover, if the teacher asked about the students' experiences or real information, the students would directly respond it. The teacher assumed that students would respond easily only if they had fun on it.

On the other hand, students would remain silent if they did not understand what the teacher said. They might also ask the teacher to explain again on what the teacher meant. Another fact was that students might vary their language. If they wanted to ask question or give comment, they would speak in Bahasa Indonesia. At other time, they would speak in English once they knew how to say it in English.

\section{CONCLUSION}

As confirmed by the teachers, their first belief is that through TSs interaction, they can promote English acquisition by exposing comprehensible input and facilitating the students to produce output. The teachers consider that English acquisition is better proposed in the early stage. Thus, the teachers often communicate the input in English, encourage their students to produce output and give corrective feedback during TSs interaction. Besides, TSs interaction may facilitate the teachers to increase the students' engagement and motivation. As what has been agreed by the teachers, TSs interaction cannot merely be focused on the materials. Building relationship is needed to make them engaged and motivated in learning. It can be done by managing students' behavior verbally, increasing students' attitude by communicating ideas and creating supportive learning atmosphere.

The second belief is that for achieving the goals of TSs interaction, during the process, the input should be comprehensible. It is done by providing language that is suitable to the students' proficiency and using some expressions as a routine. The last belief is related to the components of the TSs interaction. One of them is the teacher talk. First, the teachers believe that their talk should be dominant only for controlling the activities and the content learnt. However, it should support the students in learning the language. It may not block the students to speak more. Thus, teacher talk in TSs interaction mainly functions to facilitate the students to speak more.

These three beliefs have affected how the teachers manage the TSs interaction. By realizing the goals, the teachers can evaluate whether their verbal interaction works effectively to achieve those goals. Sometimes they have the ideal goals but the implementation does not go effectively. Further researchers on evaluating the implementation and developing the effective model of verbal interaction between teacher and the students are needed.

\section{REFERENCES}

Ani. (2017). The analysis of young learners' classroom interaction at an English course in Asia duta Wonomulyo. Unpublished bachelor's thesis. English Education Department of Tarbiyah and Teaching Science Faculty, UIN Alauddin Makassar.

Castello, D. (2015). First language acquisition and classroom language learning: Similarities and differences. Retrieved June 3, 2019 from https://www.birmingham.ac.uk/Documents/colle ge-artslaw/cels/essays/secondlanguage/FirstLanguage-Acquisition-and-ClassroomLanguage-Learning-Similarities-and Differences.pdf.

Chowdhury, M. K., \& Rashid, M. A. (2014). Classroom interaction: Tension between belief and practice (A case study of a university teacher. Global Journal of Human-Social Science: G Linguistics \& Education, 14(3).

Chu, Y. W. (2014). Teachers' beliefs in teaching English for kids at a kindergarten: A case study 


\section{Maria Setyaningsih Nernere}

Teachers' beliefs on teacher-students interaction in young learners' English class

of students from the department of applied English. English Language Teaching, 7(10), 100-112.

Creswell, J. W. (2012). Research design: Qualitative, quantitative, and mixed methods approaches (4th ed.). California: SAGE publication.

Ellis, R. (2008). The study of second language acquisition. Oxford: Oxford University Press.

Fajrinur. (2018). The beliefs of English teachers and their impacts. English Education Journal, 9(1), 145-165.

Hoque, M. E. (2016). The effect of the teacherstudents interaction: An evaluation of an EFL classroom. The Journal of EFL Education and Research, 1(1), 23-27.

Kumpulainen, K., \& Wray, D. (2002). Classroom interaction and social learning: From theory to practice. London: Routledge Falmer.

Makasau, R. (2015). Adjacency pairs in teacherstudents interaction in English day program at Mutiara Persada Elementary School Yogyakarta. Unpublished master's thesis, Sanata Dharma University.

Nation, P. (2007). The four strands, innovation in language learning and teaching. Retrieved from https://www.tandfonline.com/doi/abs/10.2167/ill t039.0.

Nugent, T. T. (2009). The impact of teacher-student interaction on student motivation and achievement. Florida: University of Central Florida.

Petek, E. (2013). Teachers' beliefs about classroom interaction and their actual practices: A qualitative case study of a native and a nonnative English teacher in class application. Procedia-Social and Behavioral Sciences, 70(1), 1195-1199.

Pianta, R. C., Hamre, B. K., \& Allen, J. P. (2012). Teacher-student relationships and engagement: Conceptualizing, measuring, and improving the capacity of classroom interactions. In S.L. Christenson et al. (eds.), Handbook of Research on Student Engagement (pp. 365-386). Berlin: Springer.

Pinter, A. (2011). Children learning second languages. London: Palgrave Macmillan.

Pujiastuti, R. T. (2013). Classroom interaction: An analysis of teacher talk and student talk in English for young learners (EYL). Journal of English and Education, 1(1), 163-172.

Puspitasari, E. (2013). Teachers' beliefs about teaching English in a bilingual primary school. Unpublished master's thesis, Sanata Dharma University.

Utami, D. N. (2016). The EFL teachers' beliefs and their teaching practices. OKARA Journal of Languages and Literature, 2(1), 135-144. 